\title{
Publications on Grundtvig and Grundtvigianism
}

\section{Publications available through Grundtvig-Selskabet, Vartov}

\section{Postage for dispatch is extra:}

Grundtvig-Studier 1979-81: DKK 50.00.

Grundtvig-Studier 1982-87: DKK 75.00.

Grundtvig-Studier 1988: DKK 125.00.

Grundtvig-Studier 1989-94: DKK 150.00.

Grundtvig-Studier 1995-96: DKK 160.00.

Grundtvig-Studier 1997-2004: DKK 170.00.

N. F. S. Grundtvig: Danne-Virke (facsimile, 1983): DKK 300.00.

N. F. S. Grundtvig: Sangvaerk bd. 6 (Kommentarbind; facsimile, 1983): DKK 20.00.

Glenthøj, Elisabeth A., Glenthøj, Johannes B., Holm, Jette, Kallesen, Leif og Toftdahl, Lars i samarbejde med Thodberg, Christian: Grundtvig. Proedikener i Vartov, 1839-42, bind 1-4, inkl. kommentarbind (bind 4), København, Vartov (2003): DKK 199,00 (så længe lager haves).

Glenthøj, Elisabeth A. og Holm, Jette i samarbejde med Christian Thodberg: Grundtvig. Proedikener $i$ Vartov, 1839-42, bind 5-8, inkl. kommentarbind (bind 8), København, Vartov (2007). DKK 492,00 (så længe lager haves).

Grønbæk, Villiam (1951), Psykologiske tanker og teorier hos Grundtvig: DKK 15.00.

Høirup, Henning (1955), Frederik Lange Grundtvig: DKK 15.00.

Johansen, Steen (1956), Taler på Marielyst: DKK 20.00.

Kofoed, Niels (1954), Grundtvig som selvbiograf: DKK 20.00.

Nielsen, Jens A. (1961), Grundtvig og Gisselfeld: DKK 15.00.

Scharling, C. I. (1947), Grundtvig og romantikken: DKK 15.00.

Toldberg, Helge (1946), Grundtvig som filolog: DKK 15.00.

Weltzer, Carl (1952), Grundtvig og Søren Kierkegaard: DKK 15.00.

\section{Contact}

Grundtvig-Selskabet, Vartov, Farvergade 27, DK-1463 København K, giro 7057598, tel.: +45 33732800, e-mail: vartov@vartov.dk, website: http://www.vartov.dk. 


\section{Publications of the Grundtvig Society}

\section{Publications of the Grundtvig Society still in print}

XXIV A. M. Allchin et al. (eds), Heritage and Prophecy. Grundtvig and the English-Speaking World. Aarhus University Press, Århus 1993.330 pp. May be purchased through booksellers or direct from Aarhus UP. DKK 198.

XXV Helge Grell, Grundtvig og Oxforderne. Grundtvigs møde med Oxfordbevagelsen og dets betydning for hans forfatterskab. Aarhus Universitetsforlag, Århus 1995. 199 s. May be purchased through booksellers, Center for Grundtvig Studier or direct from Aarhus Universitetsforlag. DKK 178.

XXVI Randi Habersaat Rode, Barneglad og engleklog. Grundtvigs selvforståelse $i$ Sang-Vark til den danske Kirke. The Royal Danish Academy of Science and Letters, København 1996. 182 s. May be purchased through The Royal Danish Academy of Science and Letters. DKK 75.

XXVII A. M. Allchin, N. F. S. Grundtvig. An Introduction to his Life and Work. Darton, Longman \& Todd, London; Aarhus University Press, Århus 1997. $338 \mathrm{pp}$. May be purchased through booksellers or direct from Aarhus University Press. DKK 298.

XXVIII S. A. J. Bradley, N. F. S. Grundtvig's Transcriptions of the Exeter Book. Grundtvig Archive Fascicle 316, 1-8 in the Royal Library Copenhagen. An Analysis. Supplement to the Registrant over N. F. S. Grundtvigs Papirer. Copenhagen 1998. $77 \mathrm{pp}$. May be purchased through the Centre for Grundtvig Studies, Aarhus University. DKK 50.

XXIX Helge Grell, Vision og virkeliggørelse. En redegørelse for Grundtvigs tanker om folkelig oplysning og en folkelig højskole og for forsøget på at virkeliggøre dem. Center for Grundtvig Studier, Aarhus Universitet, in commission with Aarhus University Press, Aarhus. 154 s. May be purchased through booksellers or direct from Aarhus University Press. DKK 150.

XXXI Bent Christensen, Omkring Grundtvigs vidskab. En undersøgelse af N. F. S. Grundtvigs forhold til den erkendelsesmassige side af det kristeligt nødvendige livsengagement. Gads Forlag, København 1998. 630 s. May be purchased through booksellers. DKK 325.

XXXII Ole Vind, Grundtvigs historiefilosofi. Gyldendal, Copenhagen 1999. 645 s. May be purchased through booksellers. DKK 300.

XXXIII A. M. Allchin et al. (eds), Grundtvig in International Perspective. Studies in the Creativity of Interaction. Aarhus University Press, Århus 2000. 209 pp. May be purchased through booksellers or direct from Aarhus University Press. DKK 248.

XXXIV Anders Holm, Historie og efterklang. En studie i N. F. S. Grundtvigs tidsskrift Danne-Virke. Odense Universitetsforlag, Odense 2001. 139 pp. May be purchased through booksellers or direct from Odense Universitetsforlag. DKK 175.

XXXV Knud Eyvin Bugge, Grundtvig og slavesagen. Aarhus Universitetsforlag, Århus 2004. 226 pp. May be purchased through booksellers or direct from Aarhus Universitetsforlag. DKK 228.

XXXVI Claus Bjørn, Grundtvig som politiker - Udgivet af Thorkild C. Lyby. Forlaget Anis, København, 2007, 264 pp. May be purchased through booksellers or direct from Forlaget Anis. DKK 295.

XXXVII S. A. J. Bradley, N. F. S. Grundtvig: A life recalled. Aarhus University Press, Århus 2007, 600 pp. May be purchased through booksellers or direct from Aarhus University Press. DKK 500. 


\section{Grundtvig-Studier}

Grundtvig-Studier 2007 contains obituaries of Sigurd Aarnes, Norway, and Paul Röhrig, Germany, two of the Grundtvig Society's international members of long standing. Also included are interesting contributions about the historical environment at the time of N. F. S. Grundtvig. The editors have endeavoured as usual to maintain a broad range of topics, among them literary history, hymn analysis and education history. In conformity with recent volumes, Englishlanguage articles are included to reflect the growing international interest in Grundtvig, this year by colleagues in Norway, England, USA, China and India.

2007 er 58. bind af Grundtvig-Selskabets årbog.

Grundtvig-Studier 2007 indeholder nekrologer over to af GrundtvigSelskabets mangeårige internationale medlemmer, Sigurd Aarnes fra Norge og Paul Röhrig fra Tyskland. Desuden offentliggøres et par interessante kilder til belysning af det historiske miljø på Grundtvigs tid. Årbogens afhandlinger spænder traditionen tro over en vifte af emner, bl.a. litteraturhistorie, salmeanalyse og skolehistorie. Endvidere videreføres de senere års bestræbelser på at inddrage den voksende internationale interesse for Grundtvig. Det sker i år i form af indlæg fra kolleger fra Norge, England, USA, Kina og Indien. 